\title{
Effect of Soil Inoculum Density and Temperature on the Incidence of Cucumber Black Root Rot
}

Kuniaki Shishido, Fukushima Agricultural Technology Center, Hiwada-machi, Koriyama, Fukushima, Japan; and Hiroyuki Murakami, Daiki Kanda, Shin-ichi Fuji, Takeshi Toda, and Hiromitsu Furuya, Faculty of Bioresource Sciences, Akita Prefectural University, Shimo-shinjo, Akita, Japan

\begin{abstract}
Shishido, K., Murakami, H., Kanda, D., Fuji, S., Toda, T., and Furuya, H. 2016. Effect of soil inoculum density and temperature on the incidence of cucumber black root rot. Plant Dis. 100:125-130.

The effects of the density of Phomopsis sclerotioides in soil and other environmental factors on black root rot of cucumber were investigated. $\mathrm{Cu}-$ cumber plants were grown in soil containing $P$. sclerotioides at 1,10 , 100 , and $1000 \mathrm{CFU} / \mathrm{g}$. Wilt incidence from 3 to 7 weeks after transplanting was strongly correlated with $P$. sclerotioides density in soil $(P<0.05)$. Root rot of squash rootstock occurred in soil with very low inoculum densities $(0.1 \mathrm{CFU} / \mathrm{g})$, and was strongly related to $P$. sclerotioides density $(Y=$ $\left.-0.3 x+1.2, R^{2}=0.743, P<0.05\right)$ at 8 weeks after transplanting. Cucumber

plants showed wilt symptoms in soil containing $1 \mathrm{CFU} / \mathrm{g}$. Wilt symptoms in cucumber plants occurred 4 to 7 days earlier in soil at $22^{\circ} \mathrm{C}$ than in soil at 27 or $17^{\circ} \mathrm{C}$. Root rot development could be predicted from the density of $P$. sclerotioides in soil and soil temperature. However, further studies on the effects of other environmental factors are required to test the linear model in commercial fields. This information is essential for determining the threshold pathogen density at which most control techniques, particularly those other than soil disinfection, will be effective.
\end{abstract}

Black root rot of cucumber (Cucumis sativus L.) caused by Phomopsis sclerotioides was first reported in 1967 by van Kesteren. Since then, the disease has been reported in Britain, Canada, Denmark, France, Germany, Malaysia, the Netherlands, Norway (Punithalingam and Holliday 1975), Austria (Bedlan 1992), Italy (Cappelli et al. 2004), and Japan (Hashimoto and Yoshino 1985; Ito et al. 2012). The fungus causes disease not only in cucumber but also in other cucurbits, although members of the genus Cucumis are most susceptible (Blancard et al. 1994). Black root rot is a serious disease of greenhouse-grown cucumber (Bruton 1996), and it also occurs in field-grown cucumber crops in Japan. It is now a major disease of cucumber in both greenhouses and fields in the northern part of Japan's main island of Honshu, the main cucumber-growing area of Japan. There is little information available about the disease cycle of black root rot. There have been no reports of pycnidia in the field. It has not been reported how $P$. sclerotioides survives in the soil during the season when host plants are not available. The fungus produces pseudomicrosclerotia and pseudostromata (van Kesteren 1967). The pseudomicrosclerotia harvested from squash roots infected by the pathogen survived for at least 2 years in sandy soil (unpublished data). Therefore, these are strong candidates for survival structures of this pathogen in soil (Blancard et al. 1994; Domsh et al. 1980; Wei et al. 2015). However, their role in the disease cycle has not yet been confirmed.

Soil disinfection by chemicals (Iwadate 2014; Iwadate et al. 2011) is the most effective technique to eliminate or reduce the damage caused by the disease but this is labor-intensive, costly, and difficult to apply at a large scale. Several other techniques that have been developed or recommended as alternatives include the use of diseasetolerant rootstocks of squash (Cucurbita ficifolia) (Horikoshi et al. 2003; Iwadate et al. 2011), reductive disinfection of soil (Kondo et al. 2013), biological control by antagonistic microorganisms (Gliocladium roseum) (Ebben and Spencer 1978; Gindrat et al. 1977; Moody and Gindrat 1977), amendments with converter slag (Iwadate

Corresponding author: H. Furuya; E-mail: furuya@ akita-pu.ac.jp

Accepted for publication 2 July 2015

http://dx.doi.org/10.1094/PDIS-12-14-1287-RE

(C) 2016 The American Phytopathological Society
2014), and several other cultivation techniques (Iwadate 2014). However, these methods have not always been sufficient to reduce the damage in commercial fields, probably when the inoculum potential of the pathogenic fungus in fields has increased beyond a threshold or when environmental conditions have been favorable for disease incidence. To increase the effectiveness of these methods, keeping the disease potential low appears to be a prerequisite. Therefore, it is necessary to clarify the relationships between inoculum potential and disease severity, and the effects of environmental or culture conditions on disease incidence.

The objectives of this study were to show the relationship between the inoculum density in soil and disease incidence in cucumber plants, and to determine the effects of environmental factors such as soil temperature and water potential on disease incidence (Murakami et al. 2006). Based on this information, prediction models for disease incidence and the degree of disease damage are also discussed.

\section{Materials and Methods}

Isolates. Isolates $\mathrm{Ph}-19$ and $\mathrm{Ps}-05$ of $P$. sclerotioides were obtained from winter squash (Cucurbita maxima $\times$ C. moschata Duch.) roots onto which cucumber (Cucumis sativus L.) was grafted. These materials were collected from Fukushima, Japan in 2005. Isolate $\mathrm{Ph}-19$ produced pycnidia and conidia on cucumber seedlings grown under aseptic conditions (unpublished data) and was confirmed to be $P$. sclerotioides, based on the morphology of its reproductive structures, according to van Kesteren (1967). Each isolate was reisolated from infected cucumber or squash roots grown in soil inoculated with the isolates once per year. The isolates were maintained on potato dextrose agar (PDA) slants at room temperature $\left(22 \pm 2^{\circ} \mathrm{C}\right)$.

Infestation of soil with $P$. sclerotioides at different $\mathrm{CFU}$ densities. To obtain the inoculum, each isolate was grown in potato dextrose broth (150 $\mathrm{ml}$ in each 1-liter conical flask) in a static culture for 4 weeks at $24^{\circ} \mathrm{C}$ in the dark. The mycelial mat produced during the incubation period was collected from several flasks, rinsed with sterilized water, blotted on sterilized filter paper to remove excess liquid, and then weighed. The mats were placed in a 200-ml metal cone cup with 120 to $140 \mathrm{ml}$ of sterilized water, then homogenized at 7,000 rpm (Ace Homogenizer AM-8; Nihonseiki Kaisha Ltd., Nagaoka, Japan) for $60 \mathrm{~s}$ with a small amount of sterilized water. The suspensions were used to prepare infested potting medium with 
high-density populations of the pathogen. The density of the pathogen (CFU per milliliter of suspension) was measured as described below. Another portion of each suspension was mixed with a small amount of potting medium and maintained at room temperature until use in experiments (within 10 weeks).

To measure $\mathrm{CFU}$, the suspensions were diluted to $10^{-4}$ and $10^{-5}$ by volume with sterilized distilled water. Then, $1 \mathrm{ml}$ of diluted suspension was spread on a PDA plate containing $0.02 \%$ lactic acid and streptomycin sulfate at $300 \mathrm{mg} /$ liter and incubated at $25^{\circ} \mathrm{C}$ for 2 weeks. Colonies that grew on the PDA plates were counted at the end of the incubation period. Five PDA plates were prepared for each suspension.

After measuring the density of the inoculum, the potting medium with a high-density population of the pathogen was diluted with additional potting medium to obtain media with $1,10,100,1,000$ or
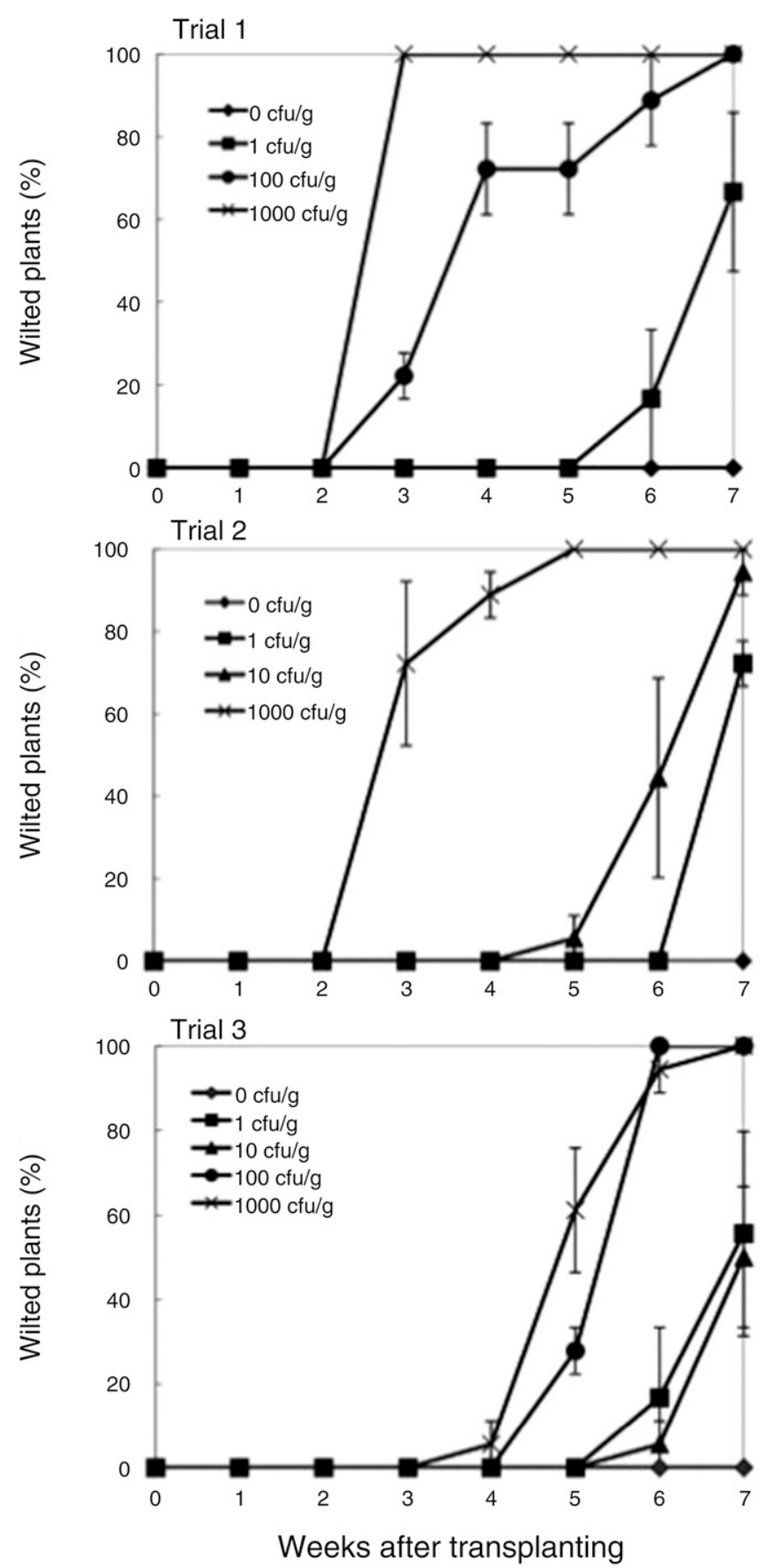

Fig. 1. Development of black root rot disease in cucumber plants grown in soils infested with Phomopsis sclerotioides at different population densities. Results of three experimental trials are shown. Bars show standard error of the mean $(P<0.05)$.
3,000 CFU/g of the pathogen. These artificially infested media were used to test the effect of pathogen population density in soil on disease incidence.

Effects of inoculum densities on disease incidence. The effects of the soil inoculum density of the fungus on disease incidence in cucumber were examined in two experiments in which plants were grown at different densities.

In the experiments with higher plant densities, six cucumber plants (C. sativus L. 'Aonagakei-Jibai'; Takii \& Co., Ltd., Kyoto, Japan) were grown in potting medium (Sakata Super Mix; Sakata Seed Co., Yokohama, Kanagawa, Japan) in a plastic container (19 by 59 by $19 \mathrm{~cm}$ ). The medium was infested with the $P$. sclerotioides isolate $\mathrm{Ph}-19$ at densities of $0,1,10,100,1,000$ or 3,000 CFU/g of medium. Cucumber seedlings (10 days old) were transplanted into the potting medium (Genki-kun Tokugo; Co-op Chemical Co. Ltd., Tokyo) and all plants were cultivated in a greenhouse. These experiments were conducted three times. The mean, maximum, and minimum temperatures were $23.5,25.5$, and $20.0^{\circ} \mathrm{C}$, respectively, in experimental trial $1 ; 20.0,21.6$, and $17.1^{\circ} \mathrm{C}$ in trial 2 ; and $19.8,20.5$, and $19.5^{\circ} \mathrm{C}$ in trial 3 . Experimental trial 3 was conducted during the winter and the mean daily air temperature outside did not exceed $12^{\circ} \mathrm{C}$; therefore, there was little fluctuation in air temperature during this experiment.

In the experiments with lower plant densities, two plants were grown in plastic containers ( 35 by 65 by $25 \mathrm{~cm}$ ). This is almost the same density as that used by commercial cucumber growers in the northern part of Japan's main island of Honshu. Cucumber (C. sativus L. 'Frontier'; Saitama Gensyu Ikusei-kai Co., Ltd., Kuki, Saitama, Japan) grafted onto squash rootstock (Cucurbita maxima $\times$ C. moschata 'Yuyu-Ikki-Kuro'; Saitama Gensyu Ikusei-kai Co., Ltd.) were grown in potting medium (Nippi-Engei-Baido-1goh; Nihon Hiryo Co., Tokyo) infested with the Ps- 05 pathogen isolate at densities of $0,0.1,1,10,100$, and 1,000 CFU/g of soil. Plants were watered using an automated drip irrigation system (Spray Stake Assemblies w/PC dripper 22500-001000; Netafim Japan, Tokyo). The experiments were conducted twice. The mean, maximum, and minimum temperatures were $24.0,31.6$, and $16.6^{\circ} \mathrm{C}$, respectively, in experimental trial 1 and $24.1,31.6$, and $16.6^{\circ} \mathrm{C}$ in trial 2 .

Effects of soil temperature and soil water content on disease incidence. For experiments on the effects of soil water content and soil temperature on disease incidence, infested potting medium was added to plastic boxes ( 15 by 22 by $30 \mathrm{~cm}$ ) and three cucumber seedlings were transplanted into each box. Then, the boxes were placed in a large plastic container ( 36 by 55 by $32 \mathrm{~cm}$ ). Three boxes were used for each treatment. The container was filled with tap water, the temperature of which was controlled by a thermopump (Cooling Thermo-Pump CTP-3000; Tokyo Rikakikai Co. Ltd., Tokyo or Cool Circulator CH-202; Scinics Co., Tokyo). The actual soil temperature during experiments was measured and recorded every 30 min by a thermorecorder (Ondo-tori T \& D Corporation, Matsumoto, Nagano, Japan). The surface of the potting medium was covered with thin plastic film to prevent excess evaporation from the soil. The soil was watered via a wooden tube $(1 \mathrm{~cm}$ in diameter and $30 \mathrm{~cm}$ long) inserted at the center of the boxes to a depth of $20 \mathrm{~cm}$. The tube had many holes ( $1 \mathrm{~cm}$ in diameter) on its side wall. The soil water potential (pF) was measured by a pF measuring device (DIK-8333/8334; Daiki Rika Kogyo Co. Ltd., Kohnosu, Japan) with sensors inserted to 10-cm soil depth. The population density of the pathogen in soil was adjusted to $10^{3} \mathrm{CFU} / \mathrm{g}$. The plants were grown for 4 to 5 weeks in a greenhouse.

To investigate the effects of soil temperature on disease incidence, the temperature of the soil was maintained at $18 \pm 1,22 \pm 1$, and $27 \pm$ $1^{\circ} \mathrm{C}$ using the water-bath method described above. The soil water potential was maintained between $\mathrm{pF} 1.9$ and 2.0. The experiments were conducted twice. The mean air temperature was 23.7 and $19.1^{\circ} \mathrm{C}$ in experimental trials 1 and 2 , respectively.

To investigate the effects of soil water content on disease incidence, the water potential of the potting medium was maintained at $\mathrm{pF} 1.7,2.0$, and 2.3. The soil temperature was maintained at $22^{\circ} \mathrm{C}$. The experiments were conducted three times. The mean, maximum, and minimum air temperatures were $23.1,26.0$, and $16.2^{\circ} \mathrm{C}$, 
respectively, in experimental trial $1 ; 19.1,27.1$, and $15.2^{\circ} \mathrm{C}$ in trial 2; and $18.2,26.0$, and $15.2^{\circ} \mathrm{C}$ in trial 3 .

Evaluation of disease severity. The disease severity was estimated by recording aboveground symptoms (wilt) and belowground symptoms (root and hypocotyl rot).

Wilt incidence was confirmed in two ways. For experiments in which plants were grown in small containers $(15$ by 22 by $30 \mathrm{~cm}$ or 19 by 59 by $19 \mathrm{~cm}$ ), the plants were considered to be diseased when more than two-thirds of the leaves wilted. For experiments in which cucumber plants were grown in large containers ( 35 by 65 by $25 \mathrm{~cm}$ ), the plants were considered to be diseased when even a single leaf wilted. In both cases, observations of plants grown in inoculated soil were conducted $1.5 \mathrm{~h}$ after watering in the morning.

If necessary, the development of disease symptoms was estimated by calculating the percentage of wilted leaves out of total leaves, excluding the top three immature leaves on each plant.

At the end of the experiments, the belowground parts of cucumber or winter squash rootstocks were removed from the soil and the severity of black root rot in the hypocotyl and root was evaluated.

Table 1. Simple regression analyses between disease incidence (wilt) in cucumber plants and population density of Phomopsis sclerotioides in soil ${ }^{\mathrm{Z}}$

\begin{tabular}{ccrrr}
\hline \multirow{2}{*}{$\begin{array}{c}\text { Weeks after } \\
\text { transplanting }\end{array}$} & $\begin{array}{c}\text { Regression } \\
\text { equation }\end{array}$ & \multicolumn{2}{c}{ ANOVA } & \multirow{2}{*}{\begin{tabular}{c} 
Coefficient of \\
\cline { 3 - 4 } determination $\boldsymbol{R}^{\mathbf{2}}$
\end{tabular}} \\
\hline Trial 1 & & $\boldsymbol{P}$ value & & \\
3 & $Y=28.6 x-8.7$ & 22.40 & 0.0021 & 0.762 \\
4 & $Y=33.3 x+0.0$ & 196.00 & $<0.0001$ & 0.966 \\
5 & $Y=33.7 x+1.2$ & 139.33 & $<0.0001$ & 0.952 \\
6 & $Y=29.0 x+20.2$ & 27.94 & 0.0011 & 0.800 \\
7 & $Y=11.9 x+69.0$ & 5.65 & 0.0492 & 0.446 \\
Trial 2 & & & & \\
3 & $Y=9.92 x-3.97$ & 27.60 & 0.0012 & 0.798 \\
4 & $Y=23.8 x-9.52$ & 36.90 & 0.0005 & 0.840 \\
5 & $Y=33.3 x-11.1$ & 65.30 & $<0.0001$ & 0.903 \\
6 & $Y=32.9 x+2.39$ & 43.10 & 0.0003 & 0.860 \\
7 & $Y=8.33 x+77.8$ & 9.82 & 0.0165 & 0.584 \\
Trial 3 & & & & \\
4 & $Y=1.7 x-1.1$ & 1.96 & 0.1921 & 0.164 \\
5 & $Y=21.1 x-9.4$ & 27.98 & 0.0004 & 0.737 \\
6 & $Y=32.8 x+5.0$ & 19.18 & 0.0014 & 0.657 \\
7 & $Y=18.3 x+48.9$ & 7.33 & 0.0221 & 0.423 \\
\hline
\end{tabular}

${ }^{\mathrm{z}}$ Disease incidence $=$ percentage of plants showing wilt symptoms. Soil was divided into four portions, which were infested with $P$. sclerotioides at four densities $(0,1,10$, and 1,000 CFU/g). ANOVA $=$ analysis of variance.
The belowground parts were dried for $48 \mathrm{~h}$ at $80^{\circ} \mathrm{C}$ using a dry heat sterilizer (Advantec STA620DC; Toyo Roshi Kaisha, Ltd., Tokyo) and then weighed to obtain dry weight.

Root rot severity was calculated as follows:

$$
\begin{array}{r}
\sum(\mathrm{DI} \times \text { number of plants showing } \mathrm{DI}) / \\
\text { total number of plants observed, }
\end{array}
$$

where disease index (DI) refers the belowground part of the plant, including the belowground part of the hypocotyl and roots. The DI was defined as $0=$ no discoloration; $1=$ less than one-third of the root or hypocotyl brown to dark brown; 2 = one-third to two-thirds of the root or hypocotyl brown to dark brown, and number of lateral roots slightly decreased; $3=$ more than two-thirds of the root or hypocotyl brown to dark brown, and number of lateral roots moderately decreased; and $4=$ more than two-thirds of root or hypocotyl brown to dark brown, and number of lateral roots greatly decreased.

Statistical analysis. Data on disease severity (mean percentages of wilted plants) every week after transplanting into infested soils were analyzed by one-way analysis of variance. Differences among means were analyzed using Tukey's test $(P<0.05)$. Simple regression analyses were conducted between the disease severity or plant growth and the population density of the soil pathogen. All statistical analyses were performed with JMP 5.01 J (SAS Institute Inc., Cary, NC, USA).

\section{Results}

Effects of inoculum density on disease incidence. In cucumber plants growing on their own roots or on squash rootstock, the progress of the disease differed among soils with different pathogen inoculum densities. In cucumber plants grown on their own roots, wilt occurred in soils containing the pathogen at all densities $(1,10$, 100 , and 1,000 CFU/g). Wilt symptoms first appeared at 3 to 4 weeks after transplanting into soils infested with 100 and 1,000 CFU/g, and at 6 to 7 weeks after transplanting into soils infested with 10 or 1 CFU/g (Fig. 1). The number of wilted plants increased more rapidly in soil containing 1,000 CFU/g than in soil containing 100,10, and 1 $\mathrm{CFU} / \mathrm{g}$. In all three experimental trials, simple regression analyses showed that the disease severity in cucumber plants grown on their own roots during 3 to 7 weeks after transplanting was strongly correlated with the pathogen density in soil $(P<0.05)$ (Table 1$)$.

The total amount of root biomass produced was much lower in soils infested with the pathogen at 100 or $1,000 \mathrm{CFU} / \mathrm{g}$ than in uninfested soil. The hypocotyls and taproots of plants grown in the heavily infested soils were discolored and deformed. There were no differences in root biomass or root color among cucumber plants

\begin{tabular}{|c|c|c|c|c|c|c|}
\hline \multirow[b]{2}{*}{ CFU/g soilu } & \multirow[b]{2}{*}{ Days $(\mathbf{n})^{\mathbf{v}}$} & \multirow[b]{2}{*}{ Plants wilted $(\%)^{\mathrm{s}}$} & \multicolumn{2}{|c|}{ Disease incidence in roots ${ }^{s}$} & \multicolumn{2}{|c|}{ Cucumber fruit harvest ${ }^{t}$} \\
\hline & & & Root rot severity ${ }^{w}$ & Root weight $(\%)^{x}$ & Number of fruit $(\%)^{y}$ & Fruit weight $(\%)^{2}$ \\
\hline 0 & n.w. & $0 \mathrm{a}$ & $0 \mathrm{a}$ & $100 \mathrm{a}$ & $100 \mathrm{a}$ & $100 \mathrm{a}$ \\
\hline 0.1 & n.w. & $0 \mathrm{a}$ & $1.0 \mathrm{~b}$ & $98.5 \mathrm{a}$ & $89.4 \mathrm{a}$ & $85.0 \mathrm{a}$ \\
\hline 1 & $53.2 \mathrm{a}$ & $100 \mathrm{~b}$ & $1.3 \mathrm{~b}$ & $59.9 \mathrm{~b}$ & $58.7 \mathrm{~b}$ & $56.1 \mathrm{~b}$ \\
\hline 10 & $40.1 \mathrm{~b}$ & $100 \mathrm{~b}$ & $3.0 \mathrm{c}$ & $43.3 \mathrm{c}$ & $30.3 \mathrm{c}$ & $28.1 \mathrm{c}$ \\
\hline 100 & $21.6 \mathrm{c}$ & $95.0 \mathrm{~b}$ & $4.0 \mathrm{~d}$ & $23.4 \mathrm{~d}$ & $12.5 \mathrm{c}$ & $9.5 \mathrm{~d}$ \\
\hline 1,000 & $22.2 \mathrm{c}$ & $95.0 \mathrm{~b}$ & $4.0 \mathrm{~d}$ & $22.0 \mathrm{~d}$ & $10.1 \mathrm{c}$ & $7.6 \mathrm{~d}$ \\
\hline
\end{tabular}

Table 2. Disease incidence and cucumber growth in soil infested with Phomopsis sclerotioides at various densities ${ }^{\mathrm{r}}$

${ }_{\mathrm{r}}^{\mathrm{r}}$ Ten plants were grown in each treatment. Experiments were conducted twice, with each trial considered as a block in the statistical analysis.

s Observations were made at 8 weeks after transplanting. Statistical significance of differences among means was calculated using Steel-Dwass test. Different letters after mean values indicate significant difference $(P<0.05)$.

t Data were analyzed by one-way analysis of variance (ANOVA). Differences among means were analyzed using Tukey's test $(P<0.05)$. Different letters after mean values indicate significant difference.

u Inoculation density.

${ }^{v}$ Number of days from transplanting to first wilt. Plants with one or more wilted leaves were counted; n.w. indicates that no wilt was found until harvest time. Statistical significance of differences among means was calculated using Steel-Dwass test. Different letters after mean values indicate significant difference $(P<0.05)$

w Values shown are mean disease index of the belowground part of the plant for "Root rot severity" \pm standard error.

${ }^{\mathrm{x}}$ Root weight as a percentage of control (control $=1.8 \mathrm{~g}$ ).

${ }^{y}$ Number of fruit as a percentage of control (control $n=104$ ).

${ }^{\mathrm{z}}$ Total fruit weight as a percentage of control (control $=10.4 \mathrm{~kg}$ ). 
grown in soils infested with $1 \mathrm{CFU} / \mathrm{g}$ and $10 \mathrm{CFU} / \mathrm{g}$, as well as in uninfested soil, although the roots of some plants in soil containing $10 \mathrm{CFU} / \mathrm{g}$ were slightly discolored and damaged.

In the experiment testing the effects of inoculum density on disease incidence in cucumber plants grown on squash root stocks at lower plant densities, the cultivation conditions were similar to those used by commercial farmers in the northern part of Japan's main island of Honshu. By 8 weeks after transplanting, more than $95 \%$ of plants grown in soils infested with the pathogen at 1, 10, 100, and 1,000 CFU/g had wilted, while plants grown with $0.1 \mathrm{CFU} / \mathrm{g}$ showed no wilt symptoms (Table 2). There was no significant difference in the percentage of wilted plants among the soils containing 1 , 10,100 , and 1,000 CFU/g but the timing of wilt differed among the treatments. By 8 weeks after transplanting, the roots of plants grown in all infested soils (with pathogen densities of 1, 10, 100, and 1,000 $\mathrm{CFU} / \mathrm{g}$ ) were diseased, because their color had become light brown to brown. The root dry weight of plants grown in soils with pathogen densities of $1,10,100$, and 1,000 CFU/g was significantly lower than that of plants grown in uninfested soil. The total numbers and weights of cucumber fruit harvested from soils infested with 100 and 1,000 CFU/g were approximately $90 \%$ lower than those harvested from uninfested soil. The total numbers and weights of cucumber fruit harvested from soils infested with 10 and $1 \mathrm{CFU} / \mathrm{g}$ were also considerably lower than those harvested from uninfested soil. In soil infested with $0.1 \mathrm{CFU} / \mathrm{g}$, cucumber plants did not wilt during the growing period but the roots became brownish. For cucumber plants grown in soil infested with $0.1 \mathrm{CFU} / \mathrm{g}$, the root dry weight and the number and weight of harvested fruit were similar to those of plants grown in uninfested soil. Simple regression analyses showed that root dry

Table 3. Simple regression analyses between disease incidence or fruit yield in cucumber plants grafted onto squash plants and population density of Phomopsis sclerotioides in soil ${ }^{\mathrm{z}}$

\begin{tabular}{|c|c|c|c|c|}
\hline \multirow{2}{*}{$\begin{array}{l}\text { Outcome } \\
\text { variable/plant }\end{array}$} & \multicolumn{2}{|c|}{ ANOVA } & \multirow{2}{*}{$\begin{array}{c}\text { Regression } \\
\text { equation }\end{array}$} & \multirow[b]{2}{*}{$R^{2}$} \\
\hline & $F$ value & $P$ value & & \\
\hline Root dry weight & 344.5 & $<0.0001$ & $Y=-0.3 x+1.2$ & 0.743 \\
\hline Fruit weight & 197.5 & $<0.0001$ & $Y=-2.1 x+6.0$ & 0.947 \\
\hline Number of fruit & 170.4 & $<0.0001$ & $Y=-21.1 x+62.7$ & 0.939 \\
\hline
\end{tabular}

${ }^{\mathrm{z}}$ Soil was divided into five portions, which were infested with $P$. sclerotioides at five densities $(0,0.1,1,10$, and $1,000 \mathrm{CFG} / \mathrm{g})$. ANOVA $=$ analysis of variance and $R^{2}=$ coefficient of determination. weight, number of harvested fruit, and weight of the fruit were strongly correlated with the population density of the pathogen in soil $(P<0.05)$ (Table 3).

Effects of soil temperature on disease incidence. In cucumber plants grown in pathogen-infested soil at a temperature of $22^{\circ} \mathrm{C}$, leaves first started to wilt at 14 or 15 days after transplanting (Tables 4 and 5), 3 to 4 days earlier than in soil at $27^{\circ} \mathrm{C}$ and 7 days earlier than in soil at $17^{\circ} \mathrm{C}$. The disease incidence in the belowground parts of cucumber plants, as reflected by discoloration and impaired root development, was more severe for plants grown in soil at $22^{\circ} \mathrm{C}$ than for those grown in soil at 17 or $27^{\circ} \mathrm{C}$ in trial 1 , and those grown in soil at $17^{\circ} \mathrm{C}$ in trial 2 (Table 6).

Effects of soil water potential on disease incidence. In both experimental trials, the percentage of wilted leaves on cucumber plants grown in pathogen-infested soil tended to be higher at $\mathrm{pF} 2.3$ than at pF1.7 or 2.0 but there were few significant differences in values among the water potential treatments (Tables 7, 8, and 9). There was no significant difference in disease incidence in the belowground parts of cucumber plants among the different soil water potential treatments (Tables 7, 8, and 9).

\section{Discussion}

Ebben and Last (1973) reported that the incidence of cucumber black root rot disease was higher in soil infested with a large population of the pathogen (mycelia at $17 \mathrm{~g} /$ liter of compost) than in soil infested with a small population of the pathogen (mycelia at $1.7 \mathrm{~g} /$ liter of compost). However, that study did not explore the detailed relationship between disease incidence and pathogen densities in the soil. The results of the present study show that the disease incidence in cucumber grown on their own roots or grafted onto squash rootstock was strongly correlated with the density of the pathogen in the soil (Fig. 1; Tables 1, 2 and 3). These results confirmed that disease development is highly dependent on the soil inoculum density.

Over the last decade, black root rot of cucumber has been a devastating disease in Fukushima and Iwate prefectures, which are located in the northeast region of Japan's main island of Honshu. In these areas, cucumber is grown mainly from May to October in fields and from March to November in greenhouses. The disease has been particularly severe over the last 15 years in the central part of Fukushima Prefecture, the largest cucumber-growing area in Japan. The monthly mean temperatures in the region are $15.6^{\circ} \mathrm{C}$ (May), $19.4^{\circ} \mathrm{C}$ (June), $22.9^{\circ} \mathrm{C}$ (July), $24.4^{\circ} \mathrm{C}$ (August), $20.1^{\circ} \mathrm{C}$ (September), and $14.1^{\circ} \mathrm{C}$ (October), with a daily minimum temperature of $9.7^{\circ} \mathrm{C}$ in October and a daily maximum temperature of $29.4^{\circ} \mathrm{C}$ in August

Table 4. Effect of soil temperature on percentage of wilted leaves of cucumber caused by black root rot in experimental trial 1

\begin{tabular}{|c|c|c|c|c|c|c|c|c|c|}
\hline \multirow[b]{2}{*}{$\operatorname{Temp}\left({ }^{\circ} \mathbf{C}\right)^{\mathbf{z}}$} & \multicolumn{9}{|c|}{ Wilted leaves on each plant $(\%)^{y}$} \\
\hline & 7 DAT & 14 DAT & 17 DAT & 21 DAT & 24 DAT & 28 DAT & 31 DAT & 35 DAT & 38 DAT \\
\hline 17 & 0 & $0 \mathrm{a}$ & $0 \mathrm{a}$ & $2.8 \pm 2.8 \mathrm{a}$ & $49.8 \pm 4.8 \mathrm{a}$ & $63.0 \pm 16.4 \mathrm{a}$ & $82.5 \pm 6.1 \mathrm{a}$ & $70.4 \pm 8.0 \mathrm{a}$ & $70.5 \pm 3.5 \mathrm{a}$ \\
\hline 22 & 0 & $3.3 \pm 3.7 \mathrm{a}$ & $7.8 \pm 4.3 \mathrm{a}$ & $47.0 \pm 8.0 \mathrm{~b}$ & $86.4 \pm 5.4 \mathrm{~b}$ & $84.8 \pm 8.5 \mathrm{a}$ & $82.4 \pm 9.4 \mathrm{a}$ & $89.9 \pm 5.8 \mathrm{a}$ & $89.5 \pm 6.1 \mathrm{a}$ \\
\hline 27 & 0 & $0 \mathrm{a}$ & $4.4 \pm 4.4 \mathrm{a}$ & $22.6 \pm 8.2 \mathrm{ab}$ & $68.8 \pm 7.5 \mathrm{ab}$ & $73.1 \pm 2.7 \mathrm{a}$ & $69.0 \pm 5.5 \mathrm{a}$ & $75.5 \pm 8.8 \mathrm{a}$ & $77.0 \pm 10.6 \mathrm{a}$ \\
\hline
\end{tabular}

y Values shown are mean percentage of wilted leaves on each plant \pm standard error at number of days after transplanting into infested soil (DAT). Data were analyzed by one-way analysis of variance. Differences among means were analyzed using Tukey's test $(P<0.05)$. Different letters after mean values indicate significant difference.

${ }^{\mathrm{z}}$ Soil temperature.

Table 5. Effect of soil temperature on percentage of wilted leaves of cucumber caused by black root rot in experimental trial 2

\begin{tabular}{lclccccc}
\hline & \multicolumn{5}{c}{ Wilted leaves on each plant $(\boldsymbol{\%})^{\mathbf{y}}$} \\
\cline { 2 - 7 } Temp $\left({ }^{\circ} \mathbf{C}\right)^{\mathbf{z}}$ & 11 DAT & 15 DAT & 19 DAT & 22 DAT & 26 DAT & 29 DAT \\
\hline 17 & 0 & $0 \mathrm{a}$ & $0 \mathrm{a}$ & $36.3 \pm 25.3 \mathrm{a}$ & $33.7 \pm 26.8 \mathrm{a}$ & $72.5 \pm 14.9 \mathrm{ab}$ & $87.7 \pm 9.5 \mathrm{a}$ \\
22 & 0 & $4.4 \pm 2.2 \mathrm{a}$ & $44.6 \pm 16.6 \mathrm{~b}$ & $91.1 \pm 2.3 \mathrm{~b}$ & $84.4 \pm 11.4 \mathrm{~b}$ & $95.7 \pm 4.3 \mathrm{~b}$ & $95.7 \pm 4.3 \mathrm{a}$ \\
27 & 0 & $0 \mathrm{a}$ & $3.5 \pm 0.1 \mathrm{a}$ & $43.0 \pm 8.5 \mathrm{a}$ & $35.9 \pm 7.7 \mathrm{a}$ & $61.1 \pm 14.7 \mathrm{a}$ & $86.6 \pm 5.6 \mathrm{a}$ \\
\hline
\end{tabular}

y Values shown are mean percentage of wilted leaves on each plant \pm standard error at number of days after transplanting into infested soil (DAT). Data were analyzed by one-way analysis of variance. Differences among means were analyzed using Tukey's test $(P<0.05)$. Different letters after mean values indicate significant difference.

${ }^{z}$ Soil temperature. 
(Japan Meteorological Agency). Wilt caused by P. sclerotioides typically appears in late June or early July of most years in this region. Ebben and Last (1973) reported that the adverse effects of $P$. sclerotioides on cucumber development were greater at a soil temperature of 10 than $20^{\circ} \mathrm{C}$. Although data on soil temperature in cucumber fields in the region are not available, our results that wilt incidence was more severe at a soil temperature of 22 than 17 or $27^{\circ} \mathrm{C}$ provide a better explanation as to why wilt disease develops in late June or early July in central Fukushima, compared with the results of Ebben and Last (1973).

The soil water potential did not affect wilt incidence or the severity of root rot disease in cucumber plants. The cucumber plants showed greater shoot growth in soil at $\mathrm{pF} 1.7$ than in soil at $\mathrm{pF} 2.0$ or 2.3 but

Table 6. Effect of soil temperature on root rot severity of cucumber caused by Phomopsis sclerotioides

\begin{tabular}{lcccc}
\hline & & \multicolumn{3}{c}{$\begin{array}{c}\text { Root rot severity of plants grown in soil at each } \\
\text { temperature }\end{array}$} \\
\cline { 3 - 5 } Trial & DAT $^{\mathbf{z}}$ & $\mathbf{1 7}^{\circ} \mathbf{C}$ & $\mathbf{2 2}^{\circ} \mathbf{C}$ & $\mathbf{2 7}^{\circ} \mathbf{C}$ \\
\hline 1 & 38 & $1.6 \pm 0.1 \mathrm{a}$ & $3.6 \pm 0.4 \mathrm{~b}$ & $2.2 \pm 0.4 \mathrm{a}$ \\
2 & 32 & $3.1 \pm 0.1 \mathrm{a}$ & $4.6 \pm 0.3 \mathrm{~b}$ & $3.9 \pm 0.4 \mathrm{ab}$ \\
\hline
\end{tabular}

$y$ Values shown are mean disease index of the belowground part of the plant for root rot severity \pm standard error. Data were analyzed by one-way analysis of variance. Differences among means were analyzed using Tukey's test $(P<0.05)$. Different letters after mean values indicate significant difference.

${ }^{\mathrm{z}}$ Days after transplanting to harvest and observation. this was probably because of greater water availability. This result indicated that the incidence of wilt and root rot are not significantly affected by soil water potential in the range of $\mathrm{pF} 1.7$ to $\mathrm{pF} 2.3$.

Two pathogen isolates were used in this study. Previously, it was suggested that there were significant differences in virulence among isolates of the fungus obtained from 12 different locations in Japan (Shishido et al. 2014). At present, the differences in virulence among the isolates from Akita and Fukushima prefectures are unknown. Further research is required to characterize the virulence of the natural populations of this pathogenic fungus.

As mentioned above, some control techniques other than soil disinfection, such as the use of tolerant rootstocks (Horikoshi et al. 2003; Iwadate et al. 2011) and converter slag (Iwadate 2014), would be expected to achieve better control of the disease when applied in fields with a lower amount of inoculum of the pathogen. These techniques are valuable for ecologically based pest management $(\mathrm{Na}-$ tional Research Council 1996) and for organic production. The results of this study clearly show that the severity of this disease is highly dependent on the initial pathogen density in soil. Therefore, reducing the pathogen load to a low density would certainly reduce the disease potential and, most probably, make these techniques sufficiently successful. When applying these control techniques, information on the inoculum density in each field is indispensable. Recently, sophisticated techniques to monitor the distribution and density of soilborne pathogens have been developed. Such techniques include molecular or antibody-based methods (Babu et al. 2011; Bilodeau et al. 2012; Capote et al. 2012; Jiménez-Fernández et al. 2011; Okubara et al. 2013; Wakeham at al. 2012; Wei et al. 2015) to detect pathogens,

Table 7. Effect of soil water potential on percentage of wilted leaves and root rot severity of cucumber caused by black root rot in experimental trial 1

\begin{tabular}{|c|c|c|c|c|c|c|c|}
\hline \multirow[b]{2}{*}{$\mathbf{p F}^{\mathbf{y}}$} & \multicolumn{6}{|c|}{ Wilted leaves on each plant $(\%)^{x}$} & \multirow[b]{2}{*}{ Severity ${ }^{z}$} \\
\hline & 12 DAT & 15 DAT & 19 DAT & 23 DAT & 27 DAT & 30 DAT & \\
\hline 1.7 & 0 & $0 \mathrm{a}$ & $67.2 \pm 16.8 b$ & $92.6 \pm 3.7 \mathrm{a}$ & $90.9 \pm 9.1 \mathrm{a}$ & $81.6 \pm 11.1 \mathrm{a}$ & $1.0 \pm 0.0 \mathrm{a}$ \\
\hline 2.0 & 0 & $0 \mathrm{a}$ & $9.7 \pm 5.0 \mathrm{a}$ & $75.0 \pm 25.0 \mathrm{a}$ & $100 \mathrm{a}$ & $93.9 \pm 3.1 \mathrm{a}$ & $1.7 \pm 0.3 \mathrm{a}$ \\
\hline 2.3 & 0 & $8.3 \pm 8.3 \mathrm{a}$ & $100 \mathrm{~b}$ & $88.9 \pm 5.6 \mathrm{a}$ & $100 \mathrm{a}$ & $100 \mathrm{a}$ & $1.7 \pm 0.7 \mathrm{a}$ \\
\hline
\end{tabular}

${ }_{\mathrm{x}}$ Values shown are mean percentage of wilted leaves on each plant \pm standard error at each number of days after transplanting into infested soil (DAT). Data were analyzed by one-way analysis of variance. Differences among means were analyzed using Tukey's test $(P<0.05)$. Different letters after mean values indicate significant differences.

y Soil water potential.

${ }^{\mathrm{z}}$ Values shown are mean disease index of the belowground pan of the plant for root rot severity \pm standard error. at 30 DAT.

Table 8. Effect of soil water potential on percentage of wilted leaves and root rot severity of cucumber caused by black root rot in experimental trial 2

\begin{tabular}{|c|c|c|c|c|c|c|c|c|}
\hline \multirow[b]{2}{*}{$\mathbf{p F}^{\mathbf{y}}$} & \multicolumn{7}{|c|}{ Wilted leaves on each plant $(\%)^{x}$} & \multirow[b]{2}{*}{ Severity $^{\mathbf{z}}$} \\
\hline & 13 DAT & 17 DAT & 20 DAT & 24 DAT & 28 DAT & 31 DAT & 34 DAT & \\
\hline 1.7 & 0 & $0 \mathrm{a}$ & $8.3 \pm 8.1 \mathrm{a}$ & $69.1 \pm 10.7 \mathrm{a}$ & $93.6 \pm 3.2 \mathrm{a}$ & $95.4 \pm 2.8 \mathrm{a}$ & $98.8 \pm 1.2 \mathrm{a}$ & $2.6 \pm 0.4 \mathrm{a}$ \\
\hline 2.0 & 0 & $0 \mathrm{a}$ & $37.4 \pm 20.9 \mathrm{a}$ & $87.6 \pm 6.7 \mathrm{ab}$ & $85.3 \pm 2.6 \mathrm{a}$ & $96.9 \pm 1.6 \mathrm{a}$ & $97.5 \pm 2.5 \mathrm{a}$ & $2.3 \pm 0.2 \mathrm{a}$ \\
\hline 2.3 & 0 & $4.4 \pm 4.4 \mathrm{a}$ & $44.4 \pm 29.4 \mathrm{a}$ & $100 \mathrm{~b}$ & $95.8 \pm 1.9 \mathrm{a}$ & $100 \mathrm{a}$ & $100 \mathrm{a}$ & $2.8 \pm 0.4 \mathrm{a}$ \\
\hline
\end{tabular}

Table 9. Effect of soil water potential on percentage of wilted leaves and root rot severity of cucumber caused by black root rot in experimental trial 3

\begin{tabular}{|c|c|c|c|c|c|c|}
\hline \multirow[b]{2}{*}{$\mathbf{p F}^{\mathbf{y}}$} & \multicolumn{5}{|c|}{ Wilted leaves on each plant $(\%)^{x}$} & \multirow[b]{2}{*}{ Severityz } \\
\hline & 11 DAT & 17 DAT & 19 DAT & 23 DAT & 26 DAT & \\
\hline 1.7 & 0 & $0 \mathrm{a}$ & $19.4 \pm 10.0 \mathrm{a}$ & $95 \pm 2.5 \mathrm{ab}$ & $98.1 \pm 1.9 \mathrm{a}$ & $2.0 \pm 0.3 \mathrm{a}$ \\
\hline 2.0 & 0 & $3.7 \pm 3.7 \mathrm{a}$ & $48.1 \pm 28.9 \mathrm{a}$ & $65.9 \pm 23.0 \mathrm{a}$ & $91.7 \pm 4.2 \mathrm{a}$ & $1.4 \pm 0.3 \mathrm{a}$ \\
\hline 2.3 & 0 & $7.4 \pm 7.4 \mathrm{a}$ & $41.7 \pm 8.3 \mathrm{a}$ & $97.2 \pm 2.8 \mathrm{~b}$ & $97.2 \pm 2.8 \mathrm{a}$ & $2.0 \pm 0.2 \mathrm{a}$ \\
\hline
\end{tabular}

$x$ Values shown are mean percentage of wilted leaves on each plant \pm standard error at each number of days after transplanting into infested soil (DAT). Data were analyzed by one-way analysis of variance. Differences among means were analyzed using Tukey's test $(P<0.05)$. Different letters after mean values indicate significant differences.

y Soil water potential.

$\mathrm{z}$ Values shown are mean disease index of the belowground pan of the plant for root rot severity \pm standard error. at 26 DAT. 
including P. sclerotioides (Ito et al. 2012; Nakata et al. 2014; Shishido et al. 2010). Therefore, monitoring the pathogen density in each field could become possible in the near future. Based on this information, a wider variety of control techniques than those currently used could be adopted. This principle might be applied in integrated management strategies of many monocyclic soilborne pathogens, the incidence of which is dependent on the initial inoculum density.

Simple regression models showed that the initial population densities of the pathogenic fungus in soil were positively correlated with wilt incidence and negatively correlated with root weight and with number and weight of fruit harvested (Tables 1 and 3). These models, combined with information on the effects of environmental parameters, would provide useful information for growers to make appropriate decisions to manage the disease. Prediction of root rot severity in commercial fields could be fairly reliable based on the model obtained in this study when other conditions are equal. Further research is required to determine the effects of other factors such as chemical factors in soil (Iwadate 2014), susceptibility of rootstocks (Horikoshi et al. 2003; Iwadate et al. 2011; Wiggell and Simpson 1969), and soil microorganisms (Moody and Gindrat 1977) on the disease.

In this study, yield loss was closely related to initial inoculum density under controlled laboratory conditions. However, it could be more difficult to predict yield loss than to predict root rot severity in commercial fields based on these models. This is because yields are affected by wilt, which is caused by factors other than this disease. We have observed, in commercial fields, that cucumber plants growing on rootstocks without typical belowground symptoms of pathogen infection wilted because of water stress caused by low soil moisture and strong solar radiation. We also have observed that some plants with typical belowground symptoms did not wilt until the end of the harvest season. Thus, there may not always be a strong correlation between wilt incidence and pathogen population densities in fields.

\section{Acknowledgments}

This study was funded by Research and Development Projects for Application in Promoting New Policy of Agriculture, Forestry and Fishery provided by the Japanese Government (2010 to 2012) and the President-sponsored Research Project, Akita Prefectural University (2012 and 2013).

\section{Literature Cited}

Babu, B. K., Mesapogu, S., Sharma, A., Somasani, S. R., and Arora, D. K. 2011. Quantitative real-time PCR assay for rapid detection of plant and human pathogenic Macrophomina phaseolina from field and environmental samples. Mycologia 103:466-473.

Bedlan, G. 1992. Cucumber diseases. Pflanzenschutz (Vienna) 2:4-7. (In German with English summary)

Bilodeau, G. J., Koike, S. T., Uribe, P., and Martin, F. N. 2012. Development of an assay for rapid detection and quantification of Verticillium dahliae in soil. Phytopathology 102:331-343.

Blancard, D., Lecoq, H., and Pitrat, M. 1994:Pages 124-125, 224-225 in: A Color Atlas of Cucurbit Diseases. Manson Publishing Ltd., London.

Bruton, B. D. 1996. Phomopsis black root rot of cucumber. Page 19 in: Compendium of Cucurbit Diseases. T. A. Zitter, D. L. Hopkins, and C. E. Thomas, eds. American Phytopathological Society Press, St. Paul, MN.

Capote, N., Pastrana, A. M., Aguado, A., and Sánchez-Torres, P. 2012. Molecular tools for detection of plant pathogenic fungi and fungicide resistance. In: Plant Pathology. C. J. Cumagun, ed. Online publication. http://www.intechopen. com/books/plant-pathology/molecular-tools-for-detection-of-plant-pathogenicfungi-and-fungicide-resistance

Cappelli, C., Stravato, V. M., Carannante, G., and Parisella, R. 2004. First report of cucumber black root rot caused by Phomopsis sclerotioides in Italy. Plant Dis. $88: 425$.

Domsh, K. H., Gamsh, W., and Anderson, T. H. 1980. Compendium of Soil Fungi, Vol. 1. Academic Press, London.
Ebben, M. H., and Last, F. T. 1973. Cucumber black root rot caused by Phomopsis sclerotioides. Ann. Appl. Biol. 73:259-267.

Ebben, M. H., and Spencer, D. M. 1978. The use of antagonistic organisms for the control of black root rot of cucumber, Phomopsis sclerotioides. Ann. Appl Biol. 89:103-106.

Gindrat, D., van der Hoeven, E., and Moody, A. R. 1977. Control of Phomopsis sclerotioides with Gliocladium roseum or Trichoderma. Neth. J. Plant Pathol. 83 (Suppl. 1):429-438.

Hashimoto, K., and Yoshino, M. 1985. A new disease on cucurbits, Phomopsis black root rot. Ann. Phytopathol. Soc. Jpn. 51:94. (Abstract in Japanese)

Horikoshi, N., Fujita, Y., and Tairako, K. 2003. Occurrence of root rot in grafted cucumber caused by Phomopsis sp. in open-field cultivation. Annu. Rep. Plant Prot. Soc. North Jpn. 54:67-69. (In Japanese)

Ito, T., Fuji, H., Sato, E., Iwadate, Y., Toda, T., and Furuya, H. 2012. Detection of Phomopsis sclerotioides in commercial cucurbit field soil by nested timerelease PCR. Plant Dis. 96:515-521.

Iwadate, Y. 2014. Studies on the epidemiology and control of cucumber black root rot caused by Phomopsis sclerotioides in Iwate prefecture. Bull. Iwate Agric. Res. Cent. 13:69-160.

Iwadate, Y., Katsube, K., Hase, S., and Namai, T. 2011. Integrated control of cucumber black root rot using chloropicrin fumigation in polyethylenemulched beds of resistant rootstock of Cucurbita ficifolia. Jpn. J. Phytopathol. 77:278-286. (In Japanese)

Japan Meteorological Agency. Tables of Climatological Normals (1981-2010) Online publication. (In Japanese) http://www.data.jma.go.jp/obd/stats/data/en/ normal/normal.html and publications/periodicals: http://www.jma.go.jp/jma/ menu/report.html

Jiménez-Fernández, D., Montes-Borrego, M., Jiménez-Díaz, R. M., Navas-Cortés, J. A., and Landa, B. B. 2011. In planta and soil quantification of Fusarium oxysporum f. sp. ciceris and evaluation of Fusarium wilt resistance in chickpea with a newly developed quantitative polymerase chain reaction assay. Phytopathology 101:250-262.

Kondo, M., Nagano, T., and Onodera, Y. 2013. Continuous effects of reductive soil disinfection on black root rot of cucumber. Annu. Rep. Plant Prot. Soc. North Jpn. 64:68-71.

Moody, A. R., and Gindrat, D. 1977. Biological control of cucumber black root rot by Gliocladium roseum. Phytopathology 67:1159-1162.

Murakami, H., Fuji, S., Naito, H., and Furuya, H. 2006. Effects of population densities of Phomopsis sclerotioides in soil on the disease incidence. J. Gen. Plant Pathol. 72:213. (In Japanese with English summary)

Nakata, N., Yokoyama, T., Yoshida, S., and Ushio, S. 2014. Correlation between quantity of Phomopsis sclerotioides in soil by real-time PCR and severity by seedling test with cucumber. (Abstr) Jpn. J. Phytopathol. 80:240 (in Japanese).

National Research Council. 1996. Page 144 in: Ecologically Based Pest Management: New Solutions for a New Century. National Academy Press, Washington, DC

Okubara, P. A., Harrison, L. A., Gatch, E. W., Vandemark, G., Schroeder, K. L., and du Toit, L. J. 2013. Development and evaluation of a TaqMan real-time PCR assay for Fusarium oxysporum f. sp. spinaciae. Plant Dis. 97:927-937.

Punithalingam, E., and Holliday, P. 1975. Phomopsis sclerotioides. CMI Descriptions of Pathogenic Fungi and Bacteria No. 470. Commonwealth Mycological Institute, Kew, Surrey, UK

Shishido, M., Ohashi, T., and Momma, N. 2014. Diaporthe sclerotioides exhibits no host specificity among cucurbit species. Plant Pathol. 63:1357-1364.

Shishido, M., Sato, K., Yoshida, N., Tsukui, R., and Usami, T. 2010. PCR-based assays to detect and quantify Phomopsis sclerotioides in plant and soil. Plant Pathol. 76:21-30.

van Kesteren, H. A. 1967. 'Black root rot' in cucurbitaceae caused by Phomopsis sclerotioides nov. spec. Neth. J. Plant Pathol. 73:112-116.

Wakeham, A., Keane, G., Proctor, M., and Kennedy, R. 2012. Monitoring infection risk for air and soil-borne fungal plant pathogens using antibody and DNA techniques and mathematical models describing environmental parameters. Pages 152-156 in: Microbes in Applied Research: Current Advances and Challenges. A. Mendez-Vilas, ed. World Scientific Publishing Co., Ltd., Hackensack, NJ.

Wei, F., Fan, R., Dong, H., Shang, W., Xu, X., Zhu, H., Yang, J., and Hu, X. 2015 The threshold microsclerotial inoculum for cotton Verticillium wilt determined through wet-sieving and real-time quantitative PCR. Phytopathology 105 220-229.

Wiggell, P., and Simpson, C. J. 1969. Observations on the control of Phomopsis root rot of cucumber. Plant Pathol. 18:71-77. 